\title{
KRITIK ATAS KRITIK MATAN JONATHAN A.C. BROWN
}

\author{
Nur Kholis \\ Universitas Ahmad Dahlan Yogyakarta, Indonesia \\ Email:nur.kholis@ilha.uad.ac.id
}

\begin{abstract}
This paper examines the thesis of Jonathan A.C. Brown in his article, entitled The Rules of Matn Criticism: There Are No Rules. One of the critical issues highlighted by Jonathan A.C. Brown in this paper that deserves to be investigated is the potential for subjectivity in the practice of matn criticism. The matn criticism referred to here is more directed to the criticism of the substance of matn; that the content of a hadith must be in line with or not contradict several arguments (dali) such as verses of the Koran, more authentic hadiths, historical facts, reason and senses or science. Up to now, scholars have not agreed on what can be used as indicators of matn criticism. The potential for subjectivity can also occur in determining the coherence of the content of a hadith with the arguments mentioned earlier (dali). Using an analytical approach and the perspective of hadith sciences as an analytical tool, the author assesses what Jonathan A.C. Brown has discussed in his article as a scientific finding that deserves to be examined in depth. In addition, this paper provides a scientific argument as to why scholars place more emphasis on sanad criticism as the initial and primary step in the hadith validation process rather than matn criticism. The author also finds that the authoritative subjective theory proposed by Jonathan A.C. Brown to tackle the element of subjectivity is an idea that scientifically deserves to be used as a standard of reference and further discussion.
\end{abstract}

Keywords: Matn Criticism; Subjectivity of Narrators; Hadith Science

\begin{abstract}
Abstrak
Tulisan ini menelaah ulang pemikiran Jonathan A.C. Brown dalam karyanya The Rules Matn Criticism: There Are No Rules. Salah satu problem penting yang diangkat oleh Jonathan Brown dalam tulisan ini yang layak untuk dikaji adalah adanya potensi subjektifitas dalam praktek kerja kritik matan. Kritik matan yang dimaksud di sini lebih mengarah kepada kritik substansi matan bahwa kandungan sebuah hadis haruslah sejalan atau tidak bertentangan dengan sejumlah dalil seperti ayat al-Quran, hadis
\end{abstract}

144 | TAJDID vol. 20, No. 1, Januari - Juni 2021 
yang lebih sahih, fakta sejarah, akal dan indera atau ilmu pengetahuan. Para ulama hingga kini belum bersepakat atas apa saja yang dapat dijadikan indikator yang harus koheren, potensi subjektifitas tersebut juga dapat terjadi pada praktek menentukan koherensi kandungan sebuah hadis dengan dalil yang telah disebutkan tadi. Dengan menggunakan pendekatan analitis dan cara pandang ilmu hadis sebagai payung besar, penulis menilai apa yang diangkat oleh Jonathan A.C. Brown merupakan temuan ilmiah yang layak untuk dikaji secara mendalam. Selain itu pula, tulisan ini memberikan argumentasi ilmiah kenapa para ulama lebih menitik beratkan kritik sanad sebagai langkah awal dan pokok dalam proses validasi hadis dibanding kritik matan. Penulis juga menemukan teori subjektif otoritatif yang diajukan oleh Jonathan Brown untuk menanggulangi unsur subjektifitas merupakan sebuah gagasan yang secara ilmiah layak untuk dijadikan bahan acuan dan penelitian lebih lanjut.

Kata Kunci: Kritik Matan; Subjektivitas Perawi; Ilmu Hadis

\section{Pendahuluan}

Kritik matan merupakan salah satu bagian dari perkembangan studi hadis yang masih menjadi perhatian hingga kini. Sebagian cendekiawan memandang kurangnya perhatian para ahli hadis, utamanya periode awal dalam mengambangkan kritik matan. Ahmad Amin misalnya, menyatakan bahwa para ahli hadis telah memberikan perhatian mereka kepada studi kritik eksternal dengan melupakan studi kritik internal. ${ }^{1}$ Senada dengan hal itu, Rasyid Ridha dan Mahmud Abu Rayyah juga menyadari minimnya perhatian ulama ahli hadis di dalam persoalan pengembangan kritik matan hadis. ${ }^{2}$ Menurut al-Idlibi, problem utama kenapa perkembangan kritik matan tidak berbanding lurus kematangannya dengan rumusan kritik sanad, salah satunya adalah karena tidak

1 Amin, Duba Al-Islam, (Mesir: Maktabah al-Nahdhah al-Misriyyah, 1974), II, 130.

2 Mahmud Abu Rayyah, Adwa' 'ala al-Sunnah al-Nabawiyyah (Beirut: Dar alMa'arif, t.th), 290. Ungkapan Abu Shuhbah dalam hal ini dikutip oleh G.H.A. Juynboll, The Authenticity of the Tradition Literature: Discussion in Modern Egypt, (Leiden: E.J. Brill,1969), 139-40. 
terpisahkannya kritik matan utamanya pada kritik substansi matan dengan unsur subjektifitias.

Jonathan Brown, adalah salah satu tokoh hadis kontemporer yang juga menaruh perhatian pada perkembangan kritik matan. Pada salah satu tulisannya yang berjudul The Rules Matn Criticism: There Are No Rules, ia memaparkan beberapa problem substansial yang berkaitan dengan bangunan kritik matan. Misalnya saja, ia menyoroti tentang belum adanya kriteria kritik matan yang baku sebagaimana kriteria kritik sanad. ${ }^{3}$ Belum lagi potensi subjektifitas yang terdapat di dalam kritik yang mana hal itu menjadi alasan para ahli hadis terdahulu lebih mengedepankan kritik sanad dari pada kritik matan. Namun, bersamaan dengan itu dalam kerja para ahli hadis mereka tidak bisa menolak penggunaan kritik matan meski tidak menuliskannya secara metodologis.

Meski tidak menjadi hal yang umum, namun potensi subjektifitas pada praktek kritik matan ini memang dapat ditemukan dalam pendapat ulama, misalnya saja Rasyid Ridha. Pada satu tulisannya di majalah al-Manar yang berjudul Buthlan al-Difa' 'an Jarh Ka'b al-Abbar wa Wabb ibn Munabbih, ia meyakini bahwa matan sebuah hadis tidak boleh bertentangan dengan akal, indera dan ilmu pengetahuan yang telah pasti. Menariknya, dengan kriteria standar validasi kandungan matan ini, menurut pendapat Rasyid Ridha, hadis yang menyatakan bahwa Nabi Saw. pernah membelah bulan haruslah tidak diterima. Hadis yang dimaksud tersebut diriwayatkan banyak jalur, bahkan sampai digolongkan sebagai

3 Abdurrahman bin al-Shalah, Muqaddimah Ibn al-Shalah ed. oleh Aishah 'Abdurrahman (Kairo: Maktabah al-Mutanabbi, t,th), 7-8. Mayoritas ahli hadis telah sepakat lima tolak ukur kritik sanad: (1) sanad hadis bersambung hingga kepada Nabi (ittishal); (2) para periwayatnya bersifat adil; (3) para periwayatnya memenuhi syarat kecakapan (dhabit); (4) terhindar dari syudzuds, dan (4) tidak ber-'illah. ${ }^{3}$ M. Syuhudi Ismail, Kaedah Kesabihan Sanad Hadis: Telaab Kritis dan Tinjauan dengan Pendekatan Ilmu Sejarah, (Jakarta: Bulan Bintang 1988), 111. Kaidah baku ini disusun oleh muhadditsin periode khalaf, seperti Ibnu Shalah. Lihat selengkapnya dalam Abdurrahman bin al-Shalah, Muqaddimah Ibn al-Shalah ed. oleh Aishah 'Abdurrahman (Kairo: Maktabah al-Mutanabbi, t,th), 7-8. 
hadis mutawatir ma'nawi. ${ }^{4}$ Adapun redaksi hadisnya sebagai berikut: ${ }^{5}$

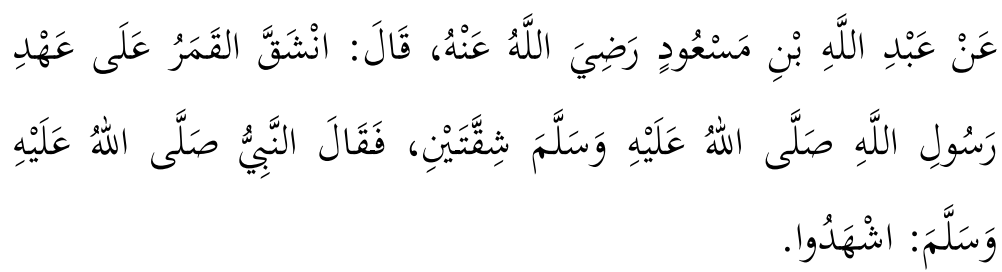

"Dari Abdullah bin Mas'ud r.a. ia berkata: "Telah terbelah bulan pada masa Rasulullah Saw., maka Nabi Saw. bersabda, "Saksikanlah oleh kalian semua!"

Meski tergolong hadis sahih bahkan sampai derajat mutawatir mánawi, tetap Rasyid Ridha tidak menerima hadis ini karena dianggap inkoheren dengan akal, tangkapan inderawi dan ilmu pengetahuan. Adapun penolakan ini secara terperinci dengan beberapa argumen berikut:

1. Rasyid Ridha menolak fenomena terbelahnya bulan karena tidak sesuai dengan gejala alam pada umumnya. Ia berkata:

$$
\begin{aligned}
& \text { ومن المعلوم بالبداهة أن انشقاق القمر أمر غريب، بل هو في منتهى } \\
& \text { الغرابة ... ... ... وانشقاق القمر غير معهود في زمن من الأزمان، } \\
& \text { فهو محال عادة، وبحسب قواعد العلم ما دام نظام لكون ثابتًا، وإن } \\
& \text { كان ممكنًا في نفسه لا يعجز الخالق تعالى إن أراده. } 6
\end{aligned}
$$

${ }^{4}$ Katsir, Tafsìr Al-Qur'ān Al-'Azim. Derajat mutawatimya hadis ini pada tataran mutawatir ma'nawi. Untuk lebih jelasnya bisa dilihat pada Ibnu Katsir, Tafsìr al-Qur'ān al-'Azim, vol. 30 (Beirut: Dār al-Fikr, t.th), 361.

${ }^{5}$ Al-Bukhāri, Șaḥh Al-Bukhārì. No. hadis. 3636, Muhammad bin Ismā'il Abū 'Abdillah al-Bukhāri al-Ja'fi, Sahịh al-Bukhārì, ed. Muḥammad Zuhair bin Nāṣir an-Nāṣir, vol. 4 (Beirut: Dār Ṭūq an-Najāh, 1422 H), 206.

${ }^{6}$ Rị̣a, 'Mas'alah Insyiqāq Al-Qamar', dalam Majallah al-Manār, edisi ke-30, (Rabi'ul Akhir 1348 H), 261. 
Nur Kholis

Kutipan paragraf di atas dengan jelas menunjukkan bahwa, bagi Rasyid Ridha terbelahnya bulan adalah fenomena yang sangat aneh dan tidak dapat diterima. Terbelahnya bulan juga adalah peristiwa yang tidak pernah dikenal dalam kurun waktu apapun. Berdasarkan ketetapan ilmu pengetahuan juga diketahui bahwa aturan di semesta ini, termasuk di dalamnya keadaan bulan akan senantiasa tetap sesuai dengan ketentuannya. Bahkan sekiranya hal itu dimungkinkan maka tentu Allah tidak akan melakukannya sebab itu akan bertentangan dengan penciptaan Alam semesta yang telah diatur oleh-Nya dalam keadaan yang baik sekali, sangat teratur rapi dan tidak ada benturan dan kesemerawutan salam sekali.

2. Rasyid Ridha tidak menerima jika hadis ini berstatus mutawatir ma'nawi. Hal ini sesuai dengan tulisannya:

$$
\begin{aligned}
& \text { فلو وقع لتوفرت الدواعي على نقله بالتواتر لشدة غرابته عند جميع الناس } \\
& \text { في جميع البلاد ومن جميع الأمم، ولو كان وقوعه آية ومعجزة لإثبات نبوة } \\
& \text { النبي صلى الله عليه وسلم لكان جميع من شاهدها من أصحاب النبي } \\
& \text { صلى الله عليه وسلم نقلها وأكثر الاستدلال والاحتجاج بها حتى كان } \\
& \text { يكون من نقلتها في رواية الصحيحين قدماء الصحابة الذين كانوا لا } \\
& \text { يكادون يفارقون النبي صلى الله عليه وسلم، ولا سيما في مثل هذه } \\
& \text { المواقف، كالخلفاء وسائر العشرة المبشرين بالجنة وغيرهم رضي الله عنهم، } \\
& \text { وقد علمت أنه لم ينقل فيهما مسندًا إلا عن عبد الله بن مسعود رضي } \\
& \text { الله عنه. }
\end{aligned}
$$

Alasan Rasyid Rida, sebagaimana kutipan di atas menolak kemutawatir-an hadis tersebut karena peristiwa terbelahnya bulan yang diinformasikan oleh hadis itu tidak pernah menjadi berita populer 
di tengah manusia. Padahal, jika memang terbelahnya bulan pernah terjadi, tentu sudah banyak manusia yang membicarakan hal itu disebabkan langka dan anehnya peristiwa tersebut. Selain dari itu, peristiwa terbelahnya bulan, sekira memang menjadi salah satu tanda kemukjizatan Nabi Saw., maka tentu seluruh sahabat yang menyaksikannya akan menukilkannya dan menjadikannya dasar dalil dan hujjah. Tentu pula Bukhari dan Muslim, di dalam meriwayatkan hadis tersebut akan menukilkannya dari para sahabat yang hampir-hampir tidak pernah berpisah dari Rasulullah Saw. seperti al-Khulafa' al-Arba'ah, sepuluh sahabat yang dijamin masuk surga dan sahabat-sahabat kibar lainnya. Namun, kenyataannya hadis ini secara sanad hanya dinukilkan dari satu sahabat saja yaitu Abdullah bin Mas'ud. ${ }^{7}$

Temuan penulis di atas yang menjadi bukti terjadinya problem subjektivitas dalam praktek validasi makna matan hadis menambah urgensi dan menariknya tulisan Jonathan A.C. Brown ini untuk dibahas dan dikaji lebih lanjut. Oleh karena itu, tulisan ini mendeskripsikan gagasan Jonathan Brown terkait kritik matan dalam hadis. Fokus penulis lebih pada pembahasan tentang bagaimana menempatkan unsur subjektifitas tersebut sebagai bagian permasalahan kritik matan. Pada akhirnya, penulis juga mencoba menanggapi secara sederhana gagasan tersebut.

Sejumlah literatur ilmiah, baik yang membahas tentang pemikiran hadis Jonathan A.C. Brown secara spesifik, maupun dalam konteks kritik matan secara umum telah dapat ditemukan. Untuk yang pertama, didapati pada tulisan Arif Budiman dkk. dengan tajuk Studi Kritik Hadis Perspektif Jonathan A.C Brown; Analisis Terhadap Three Tiered Method. ${ }^{8}$ Dengan menggunakan metode kajian pustaka, tulisan ini mencoba untuk mendeskripsikan tawaran metode investigasi hadis yang dijalankan dengan tiga

${ }^{7}$ Rida, 'Mas'alah Insyiqāq Al-Qamar', 261.

8 Arif Budiman dkk, "Studi Kritik Hadis Perspektif Jonathan A.C. Brown: Analisis terhadap Three Tiered Method, dalam Susbstansia, Vol. 22, No.1, (1 april 2020): 1-20, http://dx.doi.org/10.22373/substantia.v22i1.6853 
tingkatan. Pertama, menemukan sumber hadis yang dapat dijadikan objek penelitian. Kedua, melakukan evaluasi kredibilitas dan validasi otentisitas dari sumber tersebut. Serta menemukan sumber lain yang menguatkan sumber hadis tersebut. Dalam pengamatan penulis, kajian ini sedikit banyak memiliki jalan yang sama dengan metode rekonstruksi sumber yang ditawarkan oleh Harald Motzki. ${ }^{9}$

Sebelum itu, Nama Jonathan A.C. Brown mulai dikenal di ruang akademik secara global berkat karya monumentalnya yang berjudul The Canonization of al-Bukhari and Muslim: The Formation and Function of The sunni Hadith Canon. ${ }^{10}$ Mochammad Ismail Hasan dalam artikelnya yang berjudul Kanonisasi Jonathan Brown atas Shabih al-Bukhari meneliti karya brown tersebut dalam menyimpulkan bahwa novelty terbesar dari penelitian itu adalah Brown dalam memperlihatkan bagaimana karya Shahih al-Bukhari melewati proses yang panjang (long process) untuk kemudian dapat menjadi kitab induk hadis paling mu'tabar secara aklamasi (ijma') hingga hari ini dengan menggunakan paradigma kanoniasi karya. ${ }^{11}$

Adapun terkait dengan kajian literatur dalam konteks kritik matan secara lebih luas, didapati banyak karya ulama terdahulu hingga sekarang yang telah membahasnya secara komperhensif. Di antaranya, karya Ibnu Qayyim al-Jauziyyah yang dinggap sebagai tokoh pertama yang membahas kajian matan dalam satu tulisan independent yang diberi judul al-Manar al-Munif fi al-Shabih wa alDha if..$^{2}$ Dalam kategori tersebut, ia mengkategoresasi hadis-hadis bermasalah dilihat dari matannya. Berpijak dari tulisan ini, para

${ }^{9}$ Harald Motzki, Analysing Muslim Traditions: Studi in Legal, Exegetical and Maghạ̄̌ Ha Hàth, (Leiden: Brill, 2010), 210.

10 Brown, The Canonization of Al-Bukhari and Muslim: The Formation and Function of the Sunni Hadith Canon. (Leiden: Koninklijke Briil NV, 2007), 10.

${ }^{11}$ Mochamad Ismail Hasan, 'Kanonisasi Jonathan Brown Atas Shahih AlBukhari'. Living Islam Journal of Islamic Discourse, Vo. II, No. (1 Juni 2019): 35-45, ISSN 2621-6582 (p); 2621-6590 (e)

12 Muhammad bin Abī Bakar bin Ayyūb bin Sa'd Syamsuddīn ibn Qayyim al-Jauziyyah, Al-Manār Al-Munif Fì As-Sahịh Wa Aḍ-Da'îf, ed. 'Abd al-Fattāḥ Abū Gaddah (Ḥalab: Maktabah al-Maṭuū'ah al-Islāmiyyah, 1390 H/1970 M), 54.

150| TAJDID vol. 20, No. 1, Januari - Juni 2021 
ulama setelahnya merumuskan beberapa kriteria kritik matan menurut Ibnu Qayyim, meskipun memang secara ekspilist, tidak ternyatakan dalam kitab tersebut. Realitanya, upaya validasi matan dan pemahaman terhadapnya telah juga dilaksanakan oleh ulama sebelum Ibnu Qayyim, sebagai contoh, karya Ibnu Qutaibah dan als-Syafi' $i$ tentang hadis-hadis mukbtalif..$^{1314}$

Al-Idlibi sebagai ahli hadis generasi khalaf lalu menyusun kritik matan dengan lebih metodologis dalam rangka merespon klaim-klaim orientalis yang menuduh bahwa ulama hadis masa duku tidak memiliki peran yang signifikan dalam tumbuh kembang kritik matan. Manbaj naqd al-Matn Inda 'Ulama al-Hadits al-Nabawi, tulisan al-Idlibi menyatakan, klaim orientalis tersebut, memiliki misi untuk menjadi argumentasi bahwa kajian matan yang ada hingga kini, hakikatnya murni berasal dari kaum orientalis. Selain itu juga, mereka memiliki ambisi untuk meletakkan dasar orientalisme (nazhariyah isytiraqiyyah) terkait dengan kritik matan sebagai media untuk menyusupkan keraguan terhadap hadis. AlIdlibi sendiri pada karya itu menggunakan metode deskripsikomparatif filosofis untuk menunjukkan bukti-bukti peristiwa kritik matan semenjak masa Sahabat lalu membandingkannya dengan perkembangan kontemporer. Secara metodologis, ada empat kriteria kritik matan yang diakui mayoritas ulama menurut alIdlibi: (a) Tidak bertentangan dengan petunjuk al-Qur'an; (b) tidak bertentangan dengan hadis yang lebih kuat; (c) tidak bertentangan dengan akal sehat; (d) susunan pernyatannya menunjukkan ciri-ciri sabda kenabian. ${ }^{15}$

Al-Dumaini juga mencoba membuat kriteria kritik matan dengan pendekatan yang berlainan daripada di atas. Ia secara jelas

13 As-Syāfi'ī, Ikbtilāf Al-Hadìs, (Beirut: Dār al-Ma'rifah, 1410 H/1990 M), 100.

14 Ad-Dainurī, 'Ta'mūl Mukhtalif Al-Hadïs', (ttp: Al-Maktabah al-Islāmiyyah, $1419 \mathrm{H} / 1999 \mathrm{M}), 67$.

15 Al-Adlābì, Manhäj An-Naqd Al-Matn 'inda Ulamā Al-Hadïs, (Beirut: Dar al-Afāq al-Jadīdah, 1983 M), 108.

TAJDID vol. 20, No. 1, Januari - Juni 2021 | 151 
melakukan perbandingan kritik hadis yang selama ini dilakukan ahli hadis dengan yang selama ini dikerjakan ahli fikih. Pada tulisannya Maqayis Naqd Mutun al-Sunnah, ia berkesimpulan bahwa kriteria kritik matan yang ahli hadis dan ahli fiqh itu berbeda. Hal tersebut difaktori oleh scope dan fokus mereka yang juga berbeda. Adapun peran ulama setelahnya, adalah mengkompromikan keduanya. ${ }^{16}$

Hampir sama, Rajab mencoba meneliti perbedaan para mubadditsin dan fuqaha' pada hal kritik matan dan dari mana perbedaan itu dapat dipertemukan. Pada disertasinya Kaidah Keshabihan Matan Hadis ia berpendapat bahwa terdapat perbedaan mendasar antara kedua kubu tersebut terjadi pada pandangan mereka terkait informasi hadis yang dikaitkan dengan informasi alQur'an. menurut ahli fikih, hadis berfungsi selain bayan terhadap alQur'an, sedangkan ahli hadis masih mengakui fungsi hadis seperti takbsis, taqyid bahkan tasyri. Perbedaan ini sejatinya tidak dapat dilihat sebagai perbedaan dikotomis yang mana karena itu baiknya dikompromikan dengan membagi kaidah menjadi kaidah mayor dan minor keshahihan matan hadis. ${ }^{17}$

Literatur dengan metode yang lebih epistemologis bisa dilihat pada pemikiran Syuhudi Islam. Tulisannya Hadis Nabi yang Tekstual dan Kontekstual, menawarkan pandangan hadis juga ada yang bersifat universal, temporal dan lokal. Berpijak pada paradigman ini, makna hadis seyogyanya dilihat pada ketiga kecenderungan itu. Bagi Syuhudi, untuk bisa menempatkan matan pada ketiga kondisi itu, maka perlu ada upaya interpensi matan hadis dengan meminjam ilmu-ilmu lain secara multi-disiplin,

16 Al-Dumainī, Naqd Mutun As-Sunnah, (Riyad: Jāmi’ah al-Imām Muḥammad bin Su'ūd al-Islamiyyah, 1404 H/1984 M), 73.

${ }^{17}$ Rajab, Kaidab Kesabiban Matan Hadis (Studi Tentang Konsep Shudubudh Dan illah Menurut Muhaddithun Dan Fuqaha), (Yogyakarta: Disertasi UIN Sunan Kalijaga, 2008), 109. 
khususnya ilmu-ilmu humaniora seperti sosiologi, antropologi, psikologi dan sejarah. ${ }^{18}$

Muhammad Alfuddin dalam tulisannya juga meneliti tentang pemikiran kritik matan Muhammad al-Ghazali. Al-Ghazali sendiri bagi penulis cukup representatif dikaji, sebab, karyanya yang berjudul Al-Sunnah baina Abl al-Hadits wa Abl al-Fiqh juga menuai populer dan menimbulkan banyak diskusi di kalangan akademisi. Dengan menggunakan teori Fazlur Rahman terkait hadis dan sunah, ia mencoba menulusuri asumsi fundamental dan argumentasi yang melandasi pemikiran Muhammad al-Ghazali. Dari penulusuran itu, ia menyimpulkan bahwa ada perbedaan antara hadis dan sunah. Sunah adalah perumusan para ulama mengenai hadis, sehingga sunah melibatkan unsur interpretasi manusia dan memiliki dua sisi yaitu sisi historis yang menyatakan tindakan, dan sisi norma-norma yang menjadi petunjuk untuk generasi penerus. Sedangkan hadis adalah refleksi verbal terhadap sunah.

Berdasarkan kesimpulan itu, Alfuddin mengakui kritikan yang diajukan oleh Muhammad al-Ghazali lebih mengarah ke cara sunah itu dipahami secara historis dan norma-normanya. Oleh karena itu, al-Ghazali menyatakan hadis tidak dapat diterima apabila asinkronisasi dengan: (a) matan hadis tidak bertentangan dengan kandungan pokok isi al-Qur'an, (b) tidak bertentangan dengan rasio dan logika yang sehat, (c) tidak bertentangan dengan hadis yang lebih kuat, (d) matan hadis tidak boleh menyalahi fakta historis. ${ }^{19}$

Karya Periodisasi Kritik. Matan Hadis; Analisis Perkembangan Metodologi Kritik Matan Hadis merupakan salah satu karya yang membahas tentang kritik matan secara historis periodik.

${ }^{18}$ Ismail, S, Hadits Nabi Yang Tekstual Dan Kontekstual: Telaah Ma'anil Hadits Tentang Ajaran Islam Yang Universal, Temporal Dan Lokal. (Jakarta: Bulan Bintang 1994), 3.

${ }^{19}$ Alifuddin, M. Kritik Matan Hadis; Studi Terhadap Pemikiran Mubammad AlGhazali 1917-1996. Tesis, (Yogyakarta: Disertasi UIN Sunan Kalijaga, 1999), 91

TAJDID vol. 20, No. 1, Januari - Juni 2021 | 153 
Pendekatan ini berusaha memberikan pengertian atau informasi tentang subjek dan berusaha menetapkan dan menjelaskan dengan teliti mengenai subjek yang diteliti. Abdul Aziz berpijak pada teori historiografi Islam yang ditulis oleh Saifuddin, yang mana Saifuddin membagi periode hadis menjadi enam: periode permulaan, periode sahabat, periode tabi'in, periode atba' al-tabi in dan periode pasca al-tabi in. ${ }^{20}$

Dari berbagai literatur review di atas dapat dilihat bahwa terkait dengan kajian atas Jonathan A.C. Brown, belum ada penelitian khusus yang secara mendalam membicirakan gagasan Brown yang lebih mengarah kepada kritik matan yang berkembang dalam tradisi sunni. Padahal jika membandingkan gagasan Brown tersebut dengan kajian kritik matan yang dilakukan para ulama sebelumnya, akan terlihat secara jelas bagaimana tawaran Brown tersebut menempati posisi baru dan memberikan perspektif yang lebih fresh dalam melihat perkembangan kajian kritik matan hingga hari ini. Di samping itu, kajian kritik matan dari sudut pandang Jonathan Brown juga sangat menarik jika diperhadapkan dengan kajian-kajian para orientalis sebelumnya yang memang hingga kini, masih berkutat pada mengkritisi bangunan metodologi kritik sanad yang bersumber dari sarjana muslim. Di sinilah letak relevansi penelitian ini, yaitu mencoba untuk membahas lebih spesifik gagasan kritik matan Jonathan A.C. Brown yang belum tersentuh tadi.

\section{Riwayat Hidup dan Pendidikan}

Jonathan A.C. Brown lahir pada tahun 1977 dari pasangan Jonathan C. Brown dan seorang antropolog, Ellen Clifton Patterson. Sebelum masuk Islam pada 1997, dia adalah penganut Kristen Anglikan. Brown menamatkan sarjana muda pada tahun 2000 di Universitas Georgetown, Washington D.C. dengan

20 Aziz, A. Periodisasi Kritik Matan Hadis; Analisis Perkembangan Metodologi Kritik. Matan Hadis Sejak Periode Permulaan Sampai Periode Pasca Athba at-Tabi'in. tesis, (Yogyakarta: Disertasi UIN Sunan Kalijaga, 2015), 20. 
pridekat magna cum laude dalam sebuah penelitian tentang dunia Arab, khususnya tentang peran Universitas Amerika di Kairo sebagai perguruan tinggi bergengsi di Timur Tengah. Tingkat doktoral diselesaikannya pada tahun 2006 di Universitas Chicago dalam pemikiran Islam (Islamic Thought).

Sejak 2006 hingga 2010, Brown bekerja pada Departemen Bahasa dan Kebudayan Timur Dekat (Department of Near Eastern Languages and Civilization) Universtas Washington di Seattle, Amerika Serikat. Pada pertengahan 2010 dia menjabat sebagai asisten professor bidang Islamic Studies dan hubungan Islam-Kristen di lembaga School of Foreign Service, Universitas Georgetown.

Brown banyak menulis tentang hadis, hukum Islam, sufisme, teori leksikografi Arab, sastra Arab pra-Islam. Secara khusus dia juga mengkaji sejarah pemalsuan dan kritik sejarah yang berkembang dalam peradaban Islam, dan yang terakhir dia meneliti konflik modern yang melibatkan penganut sunni tradisional dan kelompok salafi dalam bidang pemikiran. Untuk kepentingan tersebut, dia melakukan penelitian di beberapa negara muslim seperti Mesir, Syiria, Turki, Maroko, Arab Saudi, Yaman, Indonesia, India dan Iran. Beberapa karyanya antara lain adalah:

a. Slavery and Islam: Inggris, Oneworld Academic, 2019.

b. Muhammad: A Very Short Introduction Oxford University Press, 2011.

c. Hadith: Muhammad's Legacy in the Medieval and modern World Oneworld, Foundations of Islam series, 2009.

d. The Canonization of al-Bukhari and Muslim: The Formation and Function of the Sunni Hadith Canon, Leiden: Brill, 2007.

e. "How We Know early Hadith Critics Did Matn Criticism and Why It's So Hard to Find," Islamic Law and Society 15 (2008): 143-84.

f. "The Rules Matn Criticism: There Are No Rules," Islamic Law and Society 19 (2012): 356-396. 
Nur Kholis

g. "New Data on the Delateralization of Dad and its Merger with Za' in Classical Arabic: Contributions from Old South Arabian and the Earliest Islamic Texts on D / Z Minimal Pairs," Journal of Semitic Studies 52, no.2 (2007): 335-368.

h. "The Last Days of al-Ghazzali and the Tripartite Division of Sufi World: Abu Hamid al-Ghazali's Letter to the Seljuq Vizier and Commentary." The Muslim World 96, no. 1 (2006): 89-113.

i. "Criticism of the Proto-Hadith Canon: al-Daraqutni's Adjustment of al-Bukhari and Muslim's Sahihs." Oxford Journal of Islamic Studies 15/1 (2004): 1-37.

j. "Social Context of Pre-Islamic Poetry: Poetic Imagery and Social Reality in the Mu'allaqat." Arab Studies Quarterly 25/3 (2003): 29-50.

\section{Gagasan Jonathan Brown}

Dalam sebuah tulisannya yang berjudul The Rules of Matn Critcism: There Are No Rules, Jonathan Brown mencoba menyoroti kenyataan perkembangan studi hadis utamanya dalam kajian konten hadis yang baginya perlu diberikan perhatian yang lebih. Dalam penelitian tersebut, Jonathan Brown mengungkapkan adanya ketidakjelasan metode para ulama hadis di dalam menyeleksi sebuah hadis. Seperti pada kerja Bukhari dan Muslim yang dengan tegas menolak beberapa hadis karena matannya cacat dengan beberapa indikator, antara lain: (1) ahistoris, (2) tidak masuk akal, (3) tidak sesuai dengan dogma pokok ajaran Islam dan legal hukum yang dianggap telah mutlak. Namun disaat yang sama, pada beberapa hadis ternyata diterima, meski memiliki kecacatan yang sama. ${ }^{21}$

Hal ini pun terjadi pada banyak kerja ahli hadis dimana kita bisa mempertanyakan, kenapa seseorang peneliti menolak hadis

21 Jonathan Brown, "How We Know Early Hadith Critics Did Matn Criticism and Why It's So Hard to Find", dalam Islamic Law and Society, Vol. 15, no. 2 (2008): 14, DOI: 10.1163/156851908X290574

156 | TAJDID vol. 20, No. 1, Januari - Juni 2021 
dengan alasan ketidak jelasan historis sebuah hadis sementara menerima hadis yang lain dengan kecacatan yang sama? Kenapa seorang peneliti menemukan adanya logika yang tidak masuk akal dalam sebuah hadis sementara yang lain ternyata tidak berpendapat demikian. ${ }^{22}$

Kenyataan yang demikan, menurut Jonathan Brown bermuara pada satu sumber masalah, yaitu tentang subjektifitas internal yang terdapat dalam kritik matan, dimana kualitas dan atau makna sebuah konten hadis akan senantiasa diperselisihkan oleh pembaca. Adapun pembaca, seringnya pula berbeda pendapat.

1. Afirmasi kritik matan dalam tradisi hadis sunni

Menurut Jonathan Brown, salah satu alasan ulama hadis periode awal dari kalangan sunni lebih memilih mengembangkan kritik sanad, karena validasi berbasis sanad itu lebih dianggap objektif dan dapat menjadi solusi dari problem subjektifitas internal yang lebih dimungkinkan terjadi pada kritik matan. Akal manusia dengan segala keterbatasannya, ketidak aturannya dan pemahamannya yang senantiasa berubah atas sesuatu yang mungkin dan tidak mungkin, diterima atau tidak diterima dianggap tidak bisa menjadi panduan dalam menentukan hakikat kebenaran, salah satunya di dalam mengevaluasi hadis dengan bertitik tolak pada matannya. Dengan demikian, kritik sanad diyakini memiliki keunggulan dalam menempatkan "akal" tersebut kepada sanad sebagai “otoritas" yang lebih bisa dipertanggungjawabkan. ${ }^{23}$

Terlepas dari hal tersebut, Brown justru menemukan fakta bahwa kritik konten telah diafirmasi setidaknya sejak abad ke 7/13, ketika para ulama hadis mengakui bahwa prinsip atau aturan main kritik matan merupakan bagian dari metode kritik hadis, meskipun

22 Brown, 'The Rules Of Matn Criticism: There Are No Rules', dalam Islamic Law and Society, Vol. 19, No. 4 (01 Januari 2012): 357, https://doi.org/10.1163/156851912X639923

${ }_{23}$ Brown, How We Know Early Hadith Critics Did Matn Criticism and Why It's so Hard to Find', 358. 
bagi mereka kritik konten bukan bagian dari kritik isnad. Afirmasi ini, juga diperkuat oleh beberapa pernyataan ulama ketika itu. Seperti Rabi' bin Kuthaym (80/700) yang menyatakan: "Indeed there are hadiths that have a linght as bright as day that we know (to be authentic). And there are others possesed of a darkness that is Rejected. ${ }^{24}$ Ungkapan yang juga sangat populer berasal dari Ali bin Abi Thalib "Indeed the truth is not known by men/transmitters. Rather. Know the truth and you will know its mens/transmitter.",25

Hal menarik lainnya, Kritik matan yang dikemudian hari menjadi bagian dari studi kritik hadis, dalam hasil penelitian Jonathan Brown, ternyata dipengaruhi secara langsung oleh epistemologi Muktazilah. ${ }^{26}$

Upaya mengintegrasikan epistemologi Muktazilah ke dalam kerja kritik hadis pada akhirnya menjadi batu pijakan ulama hadis untuk menyusun kriteria kritik matan. Contohnya saja al-Khatib alBaghadadi, di dalam karyanya al-Kifayah fi Ilm ar-Riwayah menuliskan indikasi hadis otentik jika terbebas dari beberapa kriteria, antara lain:

a. Ditolak berdasarkan akal. Seperti kemustahilan hadis yang memberitahu bahwa tidak ada tuhan.

b. Bertentangan dengan al-Qur'an, hadis mutawatir dan ijmá.

c. Ditransmisikan dengan narasi yang terbatas, sementara pesan yang dibawa termasuk bagian yang urgen dalam masalah agama. Jika benar hadis berasal dari Rasulullah, maka harusnya ditansmisikan dengan narasi yang jelas

${ }^{24}$ Ibn Sa'd, Kitab Al-Tabaqat Al-Kabir, ed. Ali Muhammad Umar (Kairo: Maktabah al-Khanji 2001), 306.

25 Al-Qurtubi, Al-Jami' Li-Abkam Al-Qur'an, Ed. Mubammad Ibrabim AlHifnawi Dan Mabmud Hamid Utsman (Cairo: Dar Al-Hadis, 1414/1994), 350.

${ }^{26}$ Brown, 'How We Know Early Hadīth Critics Did Matn Criticism and Why It's so Hard to Find', 151-52. 
d. Ditransmisikan hanya dengan satu jalur sementara konten hadisnya sangat penting. Sekiranya benar hadis, tentu akan disampaikan dengan banyak jalur. ${ }^{27}$

Dalam persoalan subjektifitas, para ulama yang mengafirmasi kritik matan juga mengakui hal itu merupakan bagian yang tidak terelakkan. Untuk menanggulanginya, beberapa dari ulama tersebut kemudian membuat konsep “subjektivitas otoritatif” dengan asumsi bahwa unsur subjektivitas dari seorang yang memiliki otoritas lebih diterima dibanding yang lain. Seorang ulama dikatakan memiliki otoritas dilihat dari lamanya belajar (thul almujalasah), penelitian dan pengalaman..$^{28}$ Dalam sebuah tulisannya, tentang metodologi hadis, salah satu Ulama Mesir Daqiq al-'Id memperkenalkan gagasan "kompetensi eksperimental" sebagai bagian dari kemampuan untuk mengenali hadis dari matannya. Gagasan ini menawarkan kesimpulan bahwa seseorang yang telah mengeksplorasi secara intens hadis-hadis Nabi Saw., maka ia telah membentuk kemampuan untuk mengetahui sebuah perkataan itu otentik dari Nabi atau tidak, hanya dengan melihat bentuk dan konteks hadisnya. ${ }^{29}$

Gagasan ini kemudian dikembangkan dengan istilah kemampuan intuitif pada abad 20. Salah satu ulama yang berperan dalam hal ini adalah Jamaluddin Qasimi, seorang ulama dari Damaskus yang menghubungkan kualitas kesalehan dengan kemampuan mengetahui ucapan Nabi Saw. ${ }^{30}$ Dalam hal ini, Ibn Taimiyyah juga pernah berpendapat bahwa ketika dalam satu kasus, terdapat kekurangan bukti, maka intuisi yang berasal dari

27 Al-Baghdadi, Al-Jami, li Akblaq Al-Rawi Wa Adab Al-Sami, ed. Muhammad 'Ajjaj al-Khatib, (Beirut: Muassasah al-Risalah, 1997), 89.

${ }^{28}$ Lihat al-Khatib al-Baghdadi, Kitab al-Jami' Li-akblaq al-rawi wa Adab alSami, ed. Muhammad Ra'fat Sa'id (Mansoura: Dar al-Wafa, 1423/2002), vol. 2, 272.

29 Al-Id, Al-Iqtinah Fi Bayan Al-Istilah, Ed. Beirut: Dar Al- Basha'ir Al Islamiyyah, 1427/2006. ( Beirut: Dar al-Basha'ir al-Islamiyyah, 1427/2006), 228.

${ }^{30} \mathrm{Al}-\mathrm{Q}$ asimi, Qawaid al-Hadis min Funun Mushthalah al-Hadis, (Kairo: Dar al'Aqidah, 2003), 127. 
moral seorang yang bertaqwa kepada Allah dapat diterima sebagai salah satu bukti hukum yang legal. ${ }^{31} \mathrm{Al}$-Qasimi, juga mengutik Ibn Urwa al-Hanbali dan Syah al-Kirmani, yang meyakini bahwa baiknya kesalehan dan keimanan seseorang mampu mempertajam intuisi mana yang benar dan mana yang salah, argument ini kemudian didasarkan pada hadis Rasulullah yang berbunyi "Berhatihatilah kepada firasat orang beriman karena sesunggunya ia melihat dengan cabaya Alllab (Ittaqu firasat al-mukminin fa innabu yanzhuru bi nur Allab). ${ }^{32}$

2. Inkonsistensi tradisi hadis sunni dalam pengaplikasian kritik matan

Brown memberikan bukti beberapa tokoh sunni yang inkonsistensi dalam hal kritik matan. Contoh yang paling kongkrit baginya adalah al-Khatib al-Baghadadi, yang dalam pembahasan sebelumnya merupakan salah satu tokoh yang punya peran penting dalam pengembangan kritik matan. Dari hasil telusurannya, Brown mendapati bahwa meskipun al-Baghdadi mempunyai konsep kritik matan, tetapi tidak satu pun ditemukan dalam kerja kritik hadisnya, baik itu di dalam al-Kifayah maupun dalam Jami li Akhlaq al-Rawi wa Adab al-Sami yang ia secara jelas menerapkan dan mengaplikasikan kriteria kritik matan untuk menolak sebuah hadis. Bahkan Brown berani menyatakan bahwa, dalam Tarikh al-Baghadadi, dari puluhan hadis yang ia kritik, tidak satu pun yang didasari murni dengan kritik matan. Hanya ada beberapa penjelasan tentang matan, namun tetap ia lebih memilih cacatnya sanad sebagai ukuran pokok menolak hadis. ${ }^{33}$

Begitu pula dengan salah satu ulama, Jalaluddin al-Suyuti. Dalam satu kesempatan, al-Suyuti mengakui kriteria kritik matan alBaghdadi. Tetapi dalam satu kasus, ia justru dengan sangat jelas

31 Taimiyyah, Majmu'at Al -Fatawa. ed. Sayyid Husain al-Affani dan Khair Sa’id. (Mesir: al-Maktabah a-Tawfiqiyyah, t.th), vol. 2, 26.

32 Al-Qasimi, Qawaid al-Hadis min Funun Mushthalah al-Hadis, 172.

${ }^{33}$ Brown, 'The Rules Of Matn Criticism: There Are No Rules'..., 366-367 
mengingkari kritik matan. Seperti ketika al-Suyuti mencoba membuktikan kebenaran riwayat yang menyatakan bahwa orang tua Nabi telah mendapatkan keselamatan meskipun telah meninggal sebelum adanya dakwah Islam, dengan memberikan interpretasi Ibu Nabi sebenarnya telah dihidupkan kembali secaraas singkat untuk menerima pesan Nabi Saw. ${ }^{34}$

Padahal, dengan riwayat sama, beberapa ulama sunni sendiri menolak hadis tersebut karena kandungannya dianggap mustahil. Ibn Dihya contohnya, mengkritik hadis tersebut yang ia anggap telah bertentangan dengan ijma' bahwa Ibu Nabi tidak pernah dibangkitkan kembali dan bertentangan dengan beberapa ayat alQur'an, seperti firman Allah 'Wa laa tas'al an ashab al-jabim." Bagi Ibn Dihya, ayat ini menjadi teguran kepada Nabi Saw. yang berharap orang tua beluay mendapatkan kebahagiaan setelah meninggal. ${ }^{36}$

Al-Suyuti merespon kritik Ibn Dihya tersebut dengan hanya mengatakan bahwa apa yang dilakukan oleh Ibn Dihya bertentangan dengan metodologi yang selama ini dipergunakana oleh ahli hadis. untuk memperkuat argumennya, al-Suyuti kemudian mengutip Abu al-Fadhil al-Maqdisi yang membantah Ibn Hazm yang mengkritik beberapa hadis yang ia temukan dalam Shahih Bukhari dengan landasan adanya kontradiksi, al-Maqdisi mengatakan:

"Indeed Ibn Hazm, although he was a master in diverse sciences, did not follow the method of the hadith masters in his ciritcism of that hadith. And that is because the hadith masters cirticize a hadith by means of its isnad, which is the

34 As-Suyuti, Al-Ta'zim Wa Al-Minna Fi Anna Abaway Rasulillah Fi AlJannab", Silsilat Matbu'at Da'irat Al-Ma'arif Al-Utsmaniyyah, ed. Husnain Muhammad Makhluf, (Kairo: Dar Jawami’ al-Kalim, 1915), 7-8.

35 Al-Baqarah: 119. 368.

${ }^{36}$ Jonathan Brown, "The Rules Of Matn Criticism: There Are No Rules", 
Nur Kholis

menas of opproaching it (mirqat ilaybi), while that man (Ibn Hazm) criticizes it for its text (lafazh). ${ }^{37}$

3. Problem kritik matan: antara interpretasi subjektif dan ketundukan pada otoritas teks

Dalam pembahasan pokok ini, Brown memberikan dua riwayat yang satu sama lainnya memiliki implikasi problem yang cukup dalam terkait kitik matan. Pertama, riwayat yang berbunyi:

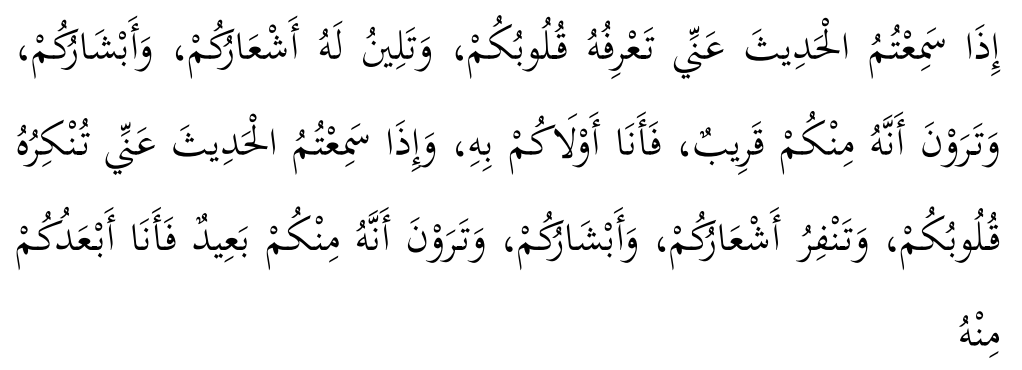

"Apabila kalian mendengar hadits dariku yang hati kalian mengenalnya bahwa itu benar, dan perasaan serta kulit kalian merasa cocok dengannya, dan kalian menganggap dekat dengannya (artinya: kemungkinan besar sabda Nabi Saw.), maka aku (Nabi) lebih dekat kepadamu. Dan apabila kalian mendengar hadits yang hati kalian mengingkarinya, sementara perasaan dan kulit kalian pun merasa tidak cocok dengannya, dan kalian menganggap itu jauh (artinya: tidak mungkin itu sabda Nabi Saw.), maka aku lebih jauh darimu dibanding hadis itu."

Kedua, ungkapan masyhur seorang sahabat yang menjadi salah satu sumber kaum muslimin pada abad ke 4/9. Riwayat ini bersumber dari Ali bin Abi Thalib dan Ibn Mas'ud, yang berbunyi:

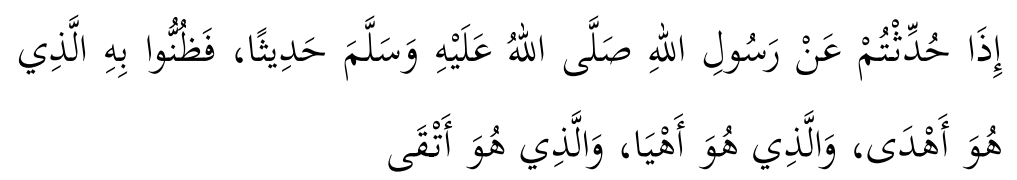

37 Al-Suyūțī, "Al-Ta'żim Wa Al-Minna Fi Anna Abaway Rasulillah Fi AlJannah", 20.

162| TAJDID Vol. 20, No. 1, Januari - Juni 2021 
"Jika kalian meriwayatkan sebuah hadis maka (fahamilah hadis tersebut dengan pemahaman) yang paling cocok, paling sesuai dengan kesalehan dan paling mampu menjadi petunjuk."

Beberapa cendekia sunni mencoba mengafirmasi kejelasan makna riwayat pertama. Tokoh fiqh Hanafi masa awal yaitu Abu Ja'far al-Tahawi (321/932) pernah membahas riwayat pertama dan berkesimpulan bahwa apa yang diajarkan Nabi sama seperti firman Allah di dalam al-Qur'an dalam hal kesesuaiannya dengan persepsi manusia tentang benar dan salah. ${ }^{38}$ Ibn Katsir juga memasukkan dan membahas riwayat ini di dalam tafsirnya. Riwayat tersebut dijadikan salah satu dalil oleh Ibn Katsir untuk menyatakan bahwa Nabi Saw. hanya menyampaikan apa yang benar dan menjauhi yang salah. Hadis ini juga menjadi salah satu inspirasi ungkapan Ibn al-Jawzi di dalam kitabanya al-Mawdu'at: "Hadis yang tidak bisa diterima adalah riwayat yang membuat kulit bergidig dan hati menolaknya. ${ }^{39}$

Yang menarik menurut Brown adalah sepanjang pembahasan ulama mengenai riwayat pertama ini, Brown tidak menemukan satu pun dari mereka yang memikirkan dan melihat bahwa hadis ini membawa resiko akan ditempatkannya rasio dan sensibilitas asumsi lebih penting dari pada sekedar menerima teks yang telah valid secara sanad. Sehingga, bagi Brown justru dengan adanya keterangan ini ketentuan diterima atau tidaknya sebuah dalil akan ditentukan oleh subjektivitas.

Brown memberikan bukti, bagaimana riwayat ini dipergunakan ulama untuk dua pendapat yang bertentangan dalam hal musik. Ahmad ibn al-Muzayyan al-Qurthubi, cendekia sunni dari Mesir, mempergunakan riwayat ini untuk menjadi alasan mempercayai sepenuhnya kepada hadis yang melarang musik,

38 Al-Ṭahāwīi, Sharh Mushkil al-āthār, ed. Shuaib al-Arnauth, (Beirut: Muassasah al-Risalah, 1494) vol.15, 346.

${ }^{39}$ Katsir, Tafsìr Al-Qur'ān Al-'Azim, (Beirut: Dār al-Fikr, 1995) vol. 2, 255.

TAJDID vol. 20, No. 1, Januari - Juni 2021 | 163 
meskipun beberapa riwayatnya bermasalah dalam hal sanad. Ia mengakui bahwa hadis-hadis tentang hukum musik, seperti yang ada di dalam beberapa kitab hadis semisal al-Jami milik al-Tirmidzi, secara jelas dikritik sendiri oleh-nya sebagai riwayat-riwayat yang lemah sanad dan kurang bukti.

Namun demikian, al-Qurtubi melanjutkan, meskipun hadishadis ini banyak kekurangannya, tetapi kandungannya sesuai dengan al-qawa'id al-syar'iyyah, sehingga tidak bertentangan dengan nilai umum syariat dan perintah di dalam al-Qur'an agar umat muslim tidak melakukan hal yang sia-sia. Al-Qurtubi pun kemudian mengutip riwayat tersebut sebagai penguat. Al-Qurtubi juga mengutip cendekia Andalusia abad pertama, Abd al-Haqq atau Ibn al-Kharrat al-Ishbili yang menyatakan bahwa "Beberapa hadis yang memuat hukum musik dan penyanyi adalah hadis-hadis yang diterima oleh hati kita dan sesuai dengan pikiran dan kecenderungan diri...."40

Berbeda dengan Murtada al-Zabidi. Di dalam komentarnya terhadap Ihya Ulumuddin karya al-Ghazali yang juga membahas tentang perdebatan musik, ia justru menolak ulama yang melarang musik dengan tetap menitik beratkan pada riwayat-riwayat yang lemah. Menariknya, ia menolak pendapat al-Qurtubi di atas, justru dengan riwayat yang dipergunakan sendiri al-Qurtubi di dalam bangunan argumennya. Ia mengatakan bahwa dengan hadis tersebut, harusnya kita menolak riwayat-riwayat yang menolak keharaman musik hanya dengan mengetahui matannya. Sebab musik itu sendiri, adalah lantunan yang secara alami diterima oleh hati, nyaman di dalam hati dan bermanfaat buat diri untuk membawa pada suasan enjoy dan rileks. ${ }^{41}$

40 Al-Qurțubī, Kashf Al-Qinā' 'an Hukm Al-Wajd Wa'l-Samā'. (Tanta: Dār al-Ṣahāba li'l-Turāth, 1412/1992), 37-40.

41 Al-Zabīīi, Ithāâf al-Sāda al-Muttaqin bi Sharh Ihyä' 'Ulüm al-Dìn, (Beirut: Muassasah at-Tarikh al-Araby, 1994), vol. 6, 525. 
Adapun terkait riwayat kedua, menurut Brown, seluruh cendekia sunni yang membahas riwayat tersebut telah menyeragamkan interpretasi mereka, yaitu pentingnya prinsip interpretasi. Salah satu tokoh besar Syaficiyyah dari Naysaburi, Ibn Khuzaimah mengutip perkatan Ali ini pada karangannya. Ia mengungkapkan bahwa pernyataan Ali ini menerangkan satu aturan penting, bahwa merupakan hal yang sangat substantif dimana seseorang memahami perkataan Nabi di bawah naungan nilai universal sunnah Nabi. Jika tidak demikian, maka dia bisa jadi akan memahami satu hadis berkontradiksi atau tidak sesuai dengan yang lain.

Ibnu Khuzaimah lalu mencontohkan, Nabi Muhammad Saw. pernah bersabda, "Seorang muslim yang biasa melakukan sebuah dosa maka tidak akan pernah masuk surga." Hadis ini tidak bisa dipahami sebagai pernyataan yang absolut. Karena, termasuk bagian keyakinan dasar, bahwa semua yang beriman dan muslim suatu hari nanti pasti akan masuk surga. Sehingga, hadis tersebut harus dipahami bahwa, "Seorang yang biasa melakukan dosa ketika bidupnya maka tidak akan masuk surga dengan mudah, semudah orang yang tidak membiasakan melakukan dosa."

Abu Bakar al-Jassas, juga menggunakan riwayat yang kedua ini ketika ia mendiskusikan hadis, "Anak zina tidak akan bisa masuk kedalam surga.” Ia menekankan bahwa jika memang riwayat ini sahih, maka hadis ini tidak boleh dipahami secara tekstual. Sebab jika diterapkan makna literal maka akan jelas bertentangan dengan ayat yang menyatakan bahwa seseorang tidak akan menanggung kesalahan orang lain. Ia lalu menyimpulkan bahwa, “Hadis yang tampaknya bertentangan dengan al-Qur'an atau hadis yang lebih sahih harus diinterpretasikan dengan jalan yang memungkinkan dan tidak menggunakan interpretasi yang bertentangan dengan dua sumber pokok tersebut."

${ }^{42} \mathrm{Abū}$ Bakr Aḥmad al-Jașṣāṣ, Uṣūl al-Jaṣṣāṣ, ed. Muḥammad Muḥammad Tāmir (Beirut: Dār al-Kutub al-' Ilmiyya, 1420/2000), 1:107-9.

TAJDID vol. 20, No. 1, Januari - Juni 2021 | 165 
Pada akhirnya diskusi atas dua riwayat yang diketengahkan oleh Brown di atas mengurucut pada dua pertanyaan pokok. Apakah semua muslim dianjurkan untuk menolak hadis yang tampaknya bertentangan atau tidak sejalan dengan ajaran Kenabian? Atau mereka berkewajiban mereintrepretasi hadis-hadis yang bermasalah itu dengan interpretasi yang lebih sesuai dengan al-Qur'an dan Sunah secara umum?

\section{Analisis Gagasan}

Sampai pada kesimpulannya, penulis menangkap bahwa Jonathan Brown hendak menggiring kita untuk menyadari letak atau sumber dari ketidakpastian kritik matan adalah menentukan mana matan yang bisa diinterpretasi dan mana yang tidak, mana matan yang sejalan dengan prinsip Islam dan mana yang tidak dan pada akhirnya berujung pada mana nilai yang absolut dalam Islam dan mana yang relatif.

Jonathan Brown menyatakan bahwa, hakikatnya permasalahan seperti ini tidak hanya terjadi di khazanah keilmuan Islam saja melainkan juga di tradisi keilmuan filsafat Yunani yang dianggap sebagai bangunan filsafat yang tertua. Di dalam filsafat Yunani diakui adanya physis dan nomos. Bahwa "What is the truly real and natural order as opposed to a culture's convention." ${ }^{* 3}$

Banyak di antara orang Islam, bagi Brown yang keliru dan berada pada pusaran kebingungan antara nomos (law) dan physics (nature). Seperti, ia mengutip kekeliruan Ibn Khaldun yang baginya naif ketika menolak riwayat yang menceritakan tentang saudari Harun al-Rasyid yang merayu Wazir Barmakid dengan alasan "She was a Noble Arab women, descended from the men around Muhammad and his uncles, so such a sin would be beneath her."

${ }^{43}$ Brown, "The Rules Of Matn Criticism: There Are No Rules", 396

${ }^{44}$ Khaldūn, Muqaddimab: An Introduction to History. trans. Franz Rosenthal, ed. N.J. Dawood (Princeton: Princeton University Press, 1989), 18-19. 
Membedakan physics dan nomos, pada akhirnya menjadi tantangan utama dalam memastikan benang antara matan hadis yang mungkin dan tidak mungkin, yang masuk akal dan tidak masuk akal. Bagi muslim, aturan "nomos" mereka akan selalu mendefinisikan apa yang mereka yakini. Tentu menjadi sebuah keanehan ketika Muslim mencoba menjadikan "nomos agnostic atau skeptik" untuk membimbing mereka dalam memahami keimanan muslim atas Kalam Allah dan Rasulullah. Para ulama terdahulu sebagai pondasi tradisi muslim telah menyontohkan bagaimana seorang yang beriman menundukkan nomos mereka yang terbatas di bawah kepastian wahyu. Mila Khatir pun pernah menulis, "That reason is never free from the blinders of convention and ignorance."

Penulis sepakat bahwa problem yang diketengahkan oleh Jonathan Brown tidak hanya menjadi persoalan dalam tubuh perkembangan ilmu hadis, melainkan juga dalam berbagai cabang keilmuan, misalnysa saja ilmu tafsir. Ingrid Matson menyatakan bahwa tantangan terbesar bagi siapa pun yang tulus berusaha mendapatkan petunjuk al-Qur'an adalah bagaimana mendengarkan firman Tuhan tanpa memaksakan ketakutan dan harapan pribadi. Pada akhirnya, bagi Ingrid Matson persoalan itu bersifat epistemologis; bagaimana seorang muslim yakin bahwa ia telah memahami makna sejati al-Qur'an, dan tidak melibatkan motif pribadi? Persoalan ini pun kemudian dibahasakan oleh Ingrid Matson berada pada pusaran intelektual dan spritual. ${ }^{45}$

Ingrid Matson memilih intelektualitas sebagai langkah awal di dalam memahami al-Qur'an. Namun bukan berarti, ia meletakkan intelektualitas tersebut di atas unsur spritualitas, sebab dalam beberapa pernyataan, ia menghimbau untuk berhati-hati dalam mempergunakan perangkat intelektualitas. Seperti ketika menjelaskan tentang kemampuan akal, bahwa seseorang harus sangat hati-hati, sebab bisa jadi ketika menjelaskan suatu ayat alQur'an, ia merasa yakin bahwa ia tengah menawarkan sebuah

${ }^{45}$ Matson, Ulumul Qur'an Zaman Kita.(Jakarta: Zaman, 2013), 269.

TAJDID vol. 20, No. 1, Januari - Juni 2021 | 167 
penafsiran. Padahal, sesungguhnya ia tengah merasionalisasikan pemikiran dan kepentingannya sendiri. ${ }^{46}$

Begitu pula, di akhir bukunya ia menutup dengan sebuah kalimat yang patut direnungi:

"Lagi pula, ada saatnya kita harus membuat keputusan dan bertindak. Kita harus memiliki keyakinan akan kekuatan Tuhan dalam membimbing kita menuju pemahaman yang benar. Namun, keyakinan itu harus selalu diiringi kerendahan hati untuk mengetahui bahwa Tuhan Maha Mengetahui". ${ }^{47}$

Menyadari hal ini, kiranya bagi penulis patut kita diskusikan kembali persoalan subjektif dan objektif yang selama ini kita pahami. Terdapat anggapan bahwa pandangan outsider terhadap teks dianggap lebih ilmiah dibanding insider itu sendiri. Atau pula ungkapan yang mengatakan, untuk mencapai puncak objektifitas kita harus lebih mengedepankan statmen historis dibanding statmen teologis. Pertanyaan sederhana yang mungkin berangkat dari apa yang disampaikan oleh Jonathan Brown dan Ingrid Matson untuk menanggapi statmen di atas; apakah seseorang yang tetap menempatkan nomos keislamannya dalam bahasa Brown, atau aspek spritualitasnya dalam bahasa Ingrid Matson atau keimanannya dalam bahasa penulis sebagai landasan dan pembimbing dari intelektualitasnya tidak bisa seobjektif orang yang berusaha melakukan penelitian diluar lingkaran 'kepentingan' sebagai seorang yang beriman dengan dalih objektivitas?

Di samping itu, jika kita mau menghubungkan gagasan Jonathan Brown terhadap kaidah al-Jarh wa al-Ta'dil, maka gagasan tersebut menguatkan ulama yang menjadikan aqidah sebagai unsur 'adalah. Hal ini senada dengan apa yang diungkapkan oleh Ahmad Luthfi Fathullah yang mengkritik Syuhudi Ismail. Dalam disertasinya, Syuhudi Ismail memberi kesan bahwa persyaratan Islam bukan merupakan hal yang disepakati dalam syarat

\footnotetext{
${ }^{46}$ Matson, 278.

${ }^{47}$ Matson, 338.
}

168 | TAJDID vol. 20, No. 1, Januari - Juni 2021 
penerimaan riwayat seorang perawi. Artinya riwayat non muslim pun condong diterima oleh banyak kritikus hadis. Sebab bagi Syuhudi Ismail terbukti dari 15 kritikus yang menyebutkan syarat 'adalah, hanya enam kritikus saja. ${ }^{48}$

Dalam hal ini, menurut Ahmad Luthfi bahwa kesimpulan tersebut keliru. Kekeliruan tersebut disebabkan oleh terpakunya Syuhudi pada penyebutan kata Islam dalam syarat. Padahal kata tersebut menjadi makna implisit atau bagian dalam banyak kata seperti taqwa, wara', shaleh dan seterusnya. Seorang perawi yang diterima riwayatnya harus yang bertakwa, maka syarat perawi harus Islam merupakan makna implisit, begitu pula dengan harus beraqidah. $^{49}$

\section{Penutup}

Dengan menelaah konsep Jonathan A.C Brown, penulis dapat melihat masih terbuka lebarnya peluang untuk meneliti hadis utamanya pada dimensi kritik matan. Hal ini dapat terlihat dari berbagai data yang disajikan oleh Jonathan Brown sendiri yang menunjukkan sejatinya praktek validasi hadis dengan melihat kandungan matannya telah dilakukan sejak masa sahabat. Bahkan, dalam beberapa kasus, terdapat hadis yang langsung ditolak tanpa melalui validasi sanad terlebih dahulu, karena kandungan matannya dianggap tidak mencerminkan hadis itu sendiri.

Adanya problem subjektivitas dalam konsep Brown tidak menunjukkan bahwa kritik substansi matan dengan pendekatan koherensial tidak dapat dilakukan. Lebih dari itu, adanya problem ini justru menunjukkan bahwa kajian terhadap hadis masih sangat terbuka lebar hingga masa kini. Fakta ini menepis anggapan yang menyatakan bahwa keilmuan hadis sudah tidak lagi dapat dikembangkan secara signifikan karena banyaknya karya ulama

48 Fathullah, 'Pengaruh Aqidah Dalam Al Jarh Wa AL Ta'dil," Hadits Nabi: Otentisitas Dan Upaya Deksturksinya'. Al-Insan, Jurnal Kajian Islam no. 2, Vol. 1 (2005), 36-37.

${ }^{49}$ Fathullah, 37. 
mengenai hadis dari berbagai aspek telah mengantarkan ilmu hadis pada kematangannya. Berkebalikan dari pendapat itu, tulisan Jonathan A.C Brown berimplikasi kepada kemustahilan finalitas atas kajian terhadap hadis, sebab kandungan hadis tersebut haruslah senantiasa didialogkan dengan berbagai perkembangan zaman yang terjadi.

\section{Daftar Pustaka}

Ad-Dainurī, Abū Muḥammad 'Abdullah bin Muslim bin Qutaibah. 'Ta'wìl Mukhtalif Al-Hadìs', 1999. http: Al- Maktabah alIslāmiyyah.

Al-Adlābī, Șalāḥuddīn bin Aḥmad. Manhäj An-Naqd Al-Matn 'inda Ulamā Al-Hadìs. Beirut: Dar al- Afāq al-Jadīdah, 1983.

Al-Baghdadi, al-Khatib. Al-Jami' Li -Akblaq Al-Rawi Wa Adab AlSami. Edited by Muhammad Ra'fat Sa'id. Dar al -Wafa, 2002.

Al-Bukhāri, Muhammad bin Ismā'il Abū 'Abdillah. Șaḥh AlBukhārì. Edited by Muḥammad Zuhair bin Nāṣir an-Nāṣir. Beirut: Dār Ṭūq an-Najāh, 2001.

Al-Dumainī, Musfar 'Azmullāh. Naqd Mutun As-Sunnah. Riyadh: Jāmi’ah al-Imām Muḥammad bin Su’ūd al-Islamiyyah, 1984.

Al-Id, Ibn Daqiq. Al-Iqtinah Fi Bayan Al-Istilah, Ed. Beirut: Dar AlBasha'ir Al - Islamiyyah, 1427/2006. Edited by Amir Hasan Sabri. Beirut: Dar al-Basha'ir al- Islamiyyah, 2006.

Al-Qurtubi, Abu Abdallah Muhamamd bin Ahmad. Al- Jami' Li Abkam Al- Qur'an, Ed. Mubammad Ibrabim Al-Hifnawi Dan Mabmud Hamid Utsman Cairo: Dar Al-Hadis, 1414/1994. Edited by Muhammad Ibrahim al-Hifnawi dan Mahmud Hamid Utsman. Beirut: Dar al-Hadis, 1994.

Al-Qurțubī, Aḥmad b. 'Umar al-Anșārī. Kashf Al-Qinā' 'an Hukm Al-Wajd Wa'l-Samā'. Tanta: Dār al-Ṣaḥāba li'l-Turāth, 1992.

Alifuddin, Muhamamd. Kritik Matan Hadis; Studi Terbadap Pemikiran Mubammad Al-Ghazali 1917-1996. Yogyakarta: Pasca

170 | TAJDID vol. 20, No. 1, Januari - Juni 2021 
Sarjana UIN Sunan Kalijaga, 1999.

Amin, Ahmad. Duha Al-Islam. Mesir: Maktabah an-Nahdhah alMisriyyah, 1974.

Al-Salah, Abdurrahman bin. Muqaddimah Ibn Al-Salah. Cairo: Maktabah al-Mutanabbi, 2006.

Al-Suyuti. Al-Ta'zim Wa Al-Minna Fi Anna Abaway Rasulillah Fi AlJannah", Silsilat Matbu'at Da'irat Al-Ma'arif Al-Utsmaniyyah. Vol. 50, 1915.

Al-Syāfi'̄', Abū 'Abdillah Muḥammad bin Idrīs bin al-'Abbās. Ikhtilāf Al-Hadìs. Beirut: Dār al-Ma’rifah, 1990.

Aziz, Abdul. Periodisasi Kritik Matan Hadis; Analisis Perkembangan Metodologi Kritik Matan Hadis Sejak Periode Permulaan Sampai Periode Pasca Athba at-Tabiin. Yogyakarta: Pasca Sarjana UIN Sunan Kalijaga, 2015.

Brown, A.C. Jontahan. 'The Rules Of Matn Criticism: There Are No Rules'. Islamic Law and Society 19, no. 4 (2012): 356-96.

Brown, Jonathan A.C. 'How We Know Early Hadith Critics Did Matn Criticism and Why It's so Hard to Find'. Islamic Law and Society 15, no. 2 (2008): 143-84. https://doi.org/10.1163/156851908X290574.

- The Canonization of Al-Bukhari and Muslim: The Formation and Function of the Sunni Hadith Canon. Leiden: oninklijke Briil NV, 2007.

Fathullah, Ahmad Luthfi. 'Pengaruh Aqidah Dalam Al Jarh Wa AL Ta'dil," Hadits Nabi: Otentisitas Dan Upaya Deksturksinya'. Jurnal Kajian Islam 1, no. 2 (2005).

Harald Motzki, Dkk. Analysing Muslim Traditions: Studi in Legal, Exegetical and Maghäri Hadith. Leiden: Brill, 2010.

Ismail, M. Syuhudi. Hadits Nabi Yang Tekstual Dan Kontekstual: Telaah Ma'anil Hadits Tentang Ajaran Islam Yang Universal, Temporal Dan Lokal. Jakarta: Bulan Bintang, 1994.

Katsir, Ibnu. Tafsìr Al-Qur'àn Al-'Azim. Beirut: Dār al-Fikr, 1995.

Khaldūn, Ibn. Muqaddimab: An Introduction to History. Edited by ed. 
Nur Kholis

N.J. Dawood Franz Rosenthal. Princeton: Princeton University Press, 1989.

Matson, Ingrid. Ulumul Qur'an Zaman Kita. Jakarta: Zaman, 2013.

Mochamad Ismail Hasan. 'Kanonisasi Jonathan Brown Atas Shahih Al-Bukhari'. Living Islam: Journal of Islamic Discourses II, no. 1 (2019): 35-54.

Muḥammad bin Abī Bakar bin Ayyūb bin Sa'd Syamsuddīn ibn Qayyim al-Jauziyyah. Al-Manār Al-Munif Fì Aș-Sahịh Wa Aḍ̂-Ḍ'îf. Halab: Maktabah al-Mațbū'ah al- Islāmiyyah, 1970.

Rajab. Kaidah Kesabihan Matan Hadis (Studi Tentang Konsep Sbudubudh Dan illah Menurut Mubaddithun Dan Fuqaha). Yogyakarta: Program Pasca sarjana UIN Sunan Kalijaga, 2008.

Rị̣a, Rasyīd. 'Mas'alah Insyiqāq Al-Qamar'. Majallah Al-Manār, 1993.

Sa'd, Muhammad Ibn. Kitab Al-Tabaqat Al-Kabir. Edited by Ali Muhammad Umar. Cairo: Maktabah al- Khanji, 2001.

Taimiyyah, Taqiyuddin Ahmad ibn. Majmu'at Al-Fatawa. Edited by Sayyid Husain al-Affani dan Khair Sa'id. Mesir: Maktabah a-Tawfiqiyyah, 1398.

172| TAJDID vol. 20, No. 1, Januari - Juni 2021 